Situs Jurnal : http://ejournal.stiepancasetia.ac.id/index.php/jieb

Jilid 7 Nomor 1 November 2021

Hal 116-135

\title{
ANALISIS SISTEM PENGENDALIAN INTERN PERSEDIAAN PADA KOPERASI TIRTA LESTARI BANJARBARU
}

\section{Maria Anastasia, Muhammad Edy}

Abstrak: Penelitian ini bertujuan untuk mengetahui sistem pengendalian intern terhadap persediaan pada Koperasi Tirta Lestari Banjarbaru selama ini dan juga memberikan masukkan sistem pengendalian intern terhadap Persediaan pada Koperasi Tirta Lestari yang seharusnya. Metode penelitian yang penulis gunakan dalam penelitian ini adalah metode kualitatif, sedangkan populasi penelitian ini adalah seluruh karyawan Koperasi Tirta Lestari yang berjumlah 17 orang dan sampel yang penulis tentukan berjumlah 4 orang dengan teknik purposive sampling. Jenis dan sumber data yang digunakan meliputi data kuantitatif dan data kualitatif serta sumber data primer dan data sekunder disamping itu, teknik pengumpulan data terdiri dari observasi, wawancara dan dokumentasi. Teknik analisis yang digunakan adalah data kualitatif dalam bentuk keterangan dan pembahasan teoritis yang bertujuan menganalisa hal-hal yang dapat dianalisa bukan dengan angka-angka tetapi dengan teori-teori yang dibuktikan dengan kenyataan yang terjadi. Hasil penelitian menunjukan pengendalian intern piutang harus memperhatikan beberapa hal, yaitu mengenai komponen dan unsur-unsur pengendalian yang terdiri dari 1 . lingkungan pengendalian dengan melihat nilai-nilai etika, kebijakan dan praktek pegawai 2. Penentuan resiko

3. Aktivitas pengendalian harus lebih memperhatikan control dan pengawasan. 4. Informasi dan komunikasi harus disediakan 5. dan pemantauan lebih memperhatikan SOP yang dijalankan agar tidak dilanggar serta memperhatikan unsur-unsurnya.

Kata Kunci: Pengadaan Barang 


\section{PENDAHULUAN \\ Latar Belakang}

Persediaan adalah suatu aktiva yang meliputi barang-barang milik perusahaan dengan maksud untuk dijual dalam periode usaha tertentu atau persediaan barang-barang yang masih dalam proses/pengerjaan produksi ataupun persediaan bahan baku yang menunggu penggunaannya dalam suatu proses produksi.

Persediaan barang dagangan adalah barang-barang yang dimiliki perusahaan untuk dijual kembali. Persediaan barang dagangan biasanya terdiri dari berbagai jenis barang dalam jumlah yang cukup besar dan menjadi bagian yang cukup berarti dari seluruh aktiva lancar yang dimiliki perusahaan. Pada sebagian perusahaan, persediaan ditetapkan dalam prosentase. Jumlah dan besarnya prosentase berbeda-beda antara perusahaan satu dengan yang lain. Besarnya prosentase yang ditetapkan merupakan cerminan pentingnya kegiatan pembelian dan penjualan persediaan dalam operasi perusahaan, selain itu besarnya prosentase persediaan juga menggambarkan besarnya prioritas persediaan dari seluruh aktiva lancar yang dimiliki perusahaan. Manajemen persediaan memegang peranan penting dalam penetapan besarnya persediaan perusahaan. Kuantitas dan jenis persediaan yang cukup harus dipertahankan untuk memenuhi permintaan konsumen, tapi disisi lain harus diperhitungkan juga biaya yang timbul akibat penyimpanan persediaan. Kuantitas dan jenis persediaan yang disimpan terlalu banyak akan memperbesar biaya penyimpanan dan pemeliharaan persediaan, sebaliknya jika persediaan yang disimpan terlalu kecil dikhawatirkan tidak mampu memenuhi permintaan konsumen. Jadi, keseimbangan persediaan harus dijaga agar tidak terlalu tinggi dan tidak terlalu rendah.

Kuantitas persediaan perlu ditentukan untuk menetapkan jumlah unit atau satuan persediaan yang dimiliki perusahaan pada tanggal neraca. Pada sebagian perusahaan, penentuan kuantitas meliputi dua hal yaitu:

1) Melakukan perhitungan fisik atas barang yang terdapat di gudang.

2) Menentukan pemilikan atas barang dalam perjalanan.

Hal ini harus dilakukan untuk menyajikan besarnya persediaan yang nantinya dilaporkan pada neraca. Untuk menyajikan laporan yang akurat perusahaan harus memiliki sistem pengendalian intern yang baik, dalam hal ini sistem pengendalian intern terhadap persediaan.

Pengendalian intern atas persediaan merupakan hal penting mengingat arti penting persediaan bagi suatu perusahaan dagang. Kesuksesan perusahaan dipengaruhi oleh baik/buruknya pengawasan atas persediaan yang dimilikinya. Perusahaan yang sukses biasanya sangat berhati-hati dalam pengawasan persediaannya. Ada banyak elemen yang harus dimiliki perusahaan untuk mendukung pengendalian intern yang baik atas persediaan.

Elemen-elemen yang harus ada untuk mendukung pengendalian intern yang baik terhadap persediaan persediaan antara lain perhitungan persediaan secara fisik dilakukan paling tidak satu tahun sekali, pembuatan prosedur yang efektif terhadap aktivitas yang secara signifikan mempengaruhi kuantitas persediaan (pembelian, penerimaan, pengiriman) melakukan penyimpanan yang baik terhadap persediaan, membatasi akses persediaan pada orang yang tidak mempunyai akses pada pencatatan persediaan, menggunakan sistem perpektual untuk persediaan yang mempunyai nilai tinggi, membeli persediaan dalam jumlah yang ekonomis, menyimpan persediaan yang cukup untuk mencegah terjadinya kekurangan persediaan, tidak menyimpan persediaan yang terlalu banyak untuk menekan dana yang tertanam dalam persediaan. Pengendalian yang baik untuk menjaga persediaan 
antara lain harus ada pemisahan fungsi pembelian, fungsi gudang dan fungsi akuntansi, transaksi pembelian harus melibatkan lebih dari satu fungsi, adanya otorisasi terhadap dokumen yang digunakan untuk melakukan transaksi yang mempengaruhi kuantitas persediaan, penggunaan dokumen yang bernomor urut, dilakukan penghitungan fisik antara catatan dengan persediaan secara periodik.

Pada praktiknya tidak semua perusahaan dagang menyadari pentingnya pengendalian intern atas persediaan yang mereka miliki. Terkadang meskipun sistem pengendalian intern telah dirancang tetapi pelaksanaannya tidak konsisten terhadap sistem yang ada sehingga akan sangat berpengaruh terhadap pelaporan persediaan. Karena kekeliruan kecil dalam hal penghitungan persediaan akan bepengaruh terhadap laba yang dilaporkan, selain itu kesalahan pelaporan akan dibawa ke periode berikutnya. Untuk itulah perlunya dilakukan perhitungan fisik paling tidak satu tahun sekali mendekati penyusunan laporan keuangan, untuk mengoreksi catatan akuntansi yang telah dibuat.

Koperasi Tirta Lestari Banjarbaru merupakan salah satu koperasi primer yang bergerak dibidang usaha simpan pinjam dan usaha perdagangan atau toko sembako seperti kebanyakan anggota koperasi yang lain. Pada Koperasi Tirta Lestari Banjarbaru anggotanya juga lebih cenderung untuk melakukan kredit dalam jangka yang panjang. Untuk menyikapi fenomena tersebut persediaan barang dagangan pada Koperasi Tirta Lestari Banjarbaru ditetapkan dalam jumlah yang kecil. Mayoritas persediaan barang dagangan yang ada pada
Koperasi Tirta Lestari Banjarbaru adalah barang-barang kebutuhan sehari-hari yang memiliki resiko kerusakan yang tinggi selain itu jika menyimpan persediaan terlalu banyak akan membutuhkan biaya yang besar untuk perawatannya.

Adapun data persediaan pada Koperasi Tirta Lestari Banjarbaru pada bulan Januari s/d Maret 2020 dapat dilihat sebagai berikut:

Tabel 1

\section{Koperasi Tirta Lestari \\ Banjarbaru Januari s/d Maret 2020}

\begin{tabular}{|c|c|c|}
\hline No & $\begin{array}{c}\text { Uraia } \\
n\end{array}$ & $\begin{array}{l}\text { Jumla } \\
\mathrm{h}\end{array}$ \\
\hline 1 & Unit Barang & 20 Item Barang \\
\hline 2 & $\begin{array}{ll}\text { Saldo } & \text { Awal } \quad \text { Per } \\
& \text { 1 Januari } 2020\end{array}$ & $\begin{array}{l}\text { Rp. } \\
127.000 .000,00\end{array}$ \\
\hline 3 & $\begin{array}{l}\text { Nilai Masuk Januari s/d } \\
\text { Maret } 2020\end{array}$ & $\begin{array}{l}\text { Rp. } \\
146.504 .000,00\end{array}$ \\
\hline 4 & \begin{tabular}{|lc} 
Nilai & Keluar \\
& Barang Januari \\
s/d Maret 2020
\end{tabular} & $\begin{array}{l}\text { Rp. } \\
113.825 .000,00\end{array}$ \\
\hline 5 & $\begin{array}{lll}\text { Saldo } & \text { Akhir } & \text { Per } \\
31 & \\
\text { Maret } & 2020\end{array}$ & $\begin{array}{l}\text { Rp. } \\
159.679 .000,00\end{array}$ \\
\hline
\end{tabular}

Sumber : Koperasi Tirta Lestari Banjarbaru, 2020

Permasalahan pada Koperasi Tirta Lestari Banjarbaru terhadap sistem pengendalian intern persediaan barang dagang dikarenakan adanya perangkapan tugas, tidak adanya dokumen surat permintaan pembelian, sistem pencatatan persediaan yang tidak dapat mengawasi dan menunjukkan kuantitas persediaan serta penarikan karyawan yang masih melalui orang dalam dalam dan tanpa seleksi sehingga memberikan dampak adanya penyelewengan barang yang dilakukan oleh pihak karyawan. Sedangkan pengendalian intern yang meliputi lingkungan pengendalian dengan tidak adanya penerapan kebijakan perekrutan, pelatihan dan pemberian rewards bagi yang berprestasi, perkiraan resiko dalam pemeriksaan kondisi barang tidak dilakukan setiap hari untuk dapat menghindari barang dari kerusakan, aktivitas pengendalian dalam pemisahan tugas tidak dilakukan 
mulai dari perencanaan, pengelolaan, penerimaan, penyimpanan dan pengeluaran, arus komunikasi intern dalam prosedur pengawasan persediaan yang tidak melibatkan beberapa fungsi terkait, dan pengawasan terhadap persediaan barang dagang tidak diawasi oleh bagian yang lebih tinggi posisinya dan secara keseluruhan. Keadaan seperti itu memang belum berdampak negatif yang menyebabkan koperasi mengalami kerugian yang besar tetapi jika hal tersebut dibiarkan berkelanjutan dalam jangka yang panjang dapat dilakukannya kecurangan.

\section{Rumusan Masalah}

Untuk mengevaluasi sistem pengendalian intern persediaan perlu dilihat sejauh mana elemen sistem pengendalian intern terhadap persediaan dirancang dan dilaksanakan. Atas dasar ini maka pertanyaan dalam penelitian dapat dirumuskan sebagai berikut:

1. Bagaimana sistem pengendalian intern persediaan yang selama ini dilakukan oleh Koperasi Tirta Lestari Banjarbaru?

2. Bagaimana sistem pengendalian intern persediaan yang seharusnya dilakukan oleh Koperasi Tirta Lestari Banjarbaru?

\section{Batasan Masalah}

Dalam pelaksanaan penelitian yang penulis lakukan, batasan masalah yang penulis angkat dalam hal ini adalah mengenai persediaan barang dagangan yang berada di unit usaha Koperasi Tirta Lestari Banjarbaru yang bergerak dalam unit usaha pertokoan.

\section{Tujuan Penelitian}

Berdasarkan rumusan masalah yang telah dikumpulkan, maka tujuan penelitian ini untuk :
1. Mengetahui sistem pengendalian intern persediaan yang selama ini dilakukan oleh Koperasi Tirta Lestari Banjarbaru.

2. Mengetahui sistem pengendalian intern persediaan yang seharusnya dilakukan oleh Koperasi Tirta Lestari Banjarbaru.

\section{Manfaat Penelitian}

Manfaat atas penelitian ini mempunyai beberapa aspek antara lain :

1. Aspek Akademis

Merupakan suatu kesempatan yang baik untuk mengaplikasikan ilmu yang telah diperoleh di bangku kuliah ke dalam praktek yang sesungguhnya khususnya dalam ilmu pengetahuan pengendalian intern persediaan dan tambahan guna civitas Sekolah Tinggi Ilmu Ekonomi Pancasetia Banjarmasin. Selain itu dapat menambah masukan bagi peneliti yang ingin mengajukan penelitian di masa yang akan datang.

2. Aspek Pengembangan Ilmu Pengetahuan Hasil penelitian dan analisa ini diharapkan dapat memberikan suatu pandangan teoritis dalam hal penerapan pengendalian intern atas persediaan, juga diharapkan dapat membantu pihak lain dalam mengimplementasikan perencanaan dan alternatif pemikiran dalam hal pengendalian intern atas persediaan barang dagangan.

3. Aspek Praktis

Hasil penelitian ini diharapkan dapat memberikan saran perbaikan sehingga dapat digunakan sebagai bahan evaluasi pada sistem pengendalian intern persediaan pada Koperasi Tirta Lestari Banjarbaru

\section{TINJAUAN PUSTAKA}

\section{Pengertian Sistem Pengendalian Intern}

Sistem pengendalian intern meliputi struktur organisasi, metode dan ukuranukuran yang dikoordinasikan untuk menjaga kekayaan organisasi, mengecek ketelitian dan keandalan data akuntansi, 
mendorong efisiensi dan mendorong dipatuhinya kebijakan manajemen. Pengendalian intern berlaku untuk semua perusahaan baik perusahaan yang pengolahan informasinya secara manual, dengan mesin pembukuan, maupun dengan komputer.

Menurut Hartadi (2018:97), sistem pengendalian intern dapat dipandang sebagai sistem sosial yang mempunyai wawasan atau makna khusus yang berada dalam organisasi perusahaan.

Sistem tersebut terdiri dari kebijakan, teknik prosedur, alat- alat fisik, dokumentasi orang-orang dengan berinteraksi satu sama lain yang diarahkan untuk:

1. Melindungi harta.

2. Menjamin terhadap terjadinya hutang yang tidak layak.

3. Menjamin ketelitian dan dapat dipercayainya data akuntansi.

4. Dapat diperolehnya operasi secara efisien.

5. Menjamin ditaatinya kebijakan perusahaan.

Menurut Hartadi (2018:2) mengungkapkan bahwa sistem pengendalian dipandang penting bagi perusahaan dengan alasan sebagai berikut:

1. Luas dan ukuran kesatuan usaha yang

kompleks dan luas sehingga manajemen harus mempercayai berbagai macam laporan- laporan dan analisis-analisis untuk mengendalikan operasi secara efektif.

2 Pengawasan dan penelaahan yang melihat pada sistem pengendalian intern yang baik mampu melindungi terhadap kelemahan manusia dan mengurangi kemungkinan kesalahan atau ketidakberesan akan terjadi.

3. Tidak praktis apabila akuntan untuk memeriksa secara keseluruhan dengan keterbatasan uang jasa.

Menurut Mulyadi (2016:163) dari tujuannya, sistem pengendalian intern dapat dibagi menjadi dua macam, yakni:

1. Pengendalian intern akuntansi (internal accounting control)

Pengendalian intern akuntansi meliputi struktur organisasi, metode dan ukuranukuran yang dikoordinasikan terutama untuk menjaga kekayaan organisasi dan dapat dipercayainya catatan akuntansi serta dirancang untuk meyakinkan halhal berikut ini :

a. Transaksi-transaksi dilaksanakan sesuai dengan persetujuan atau wewenang manajemen.

b. Transaksi dicatat agar memudahkan penyiapan laporan keuangan yang sesuai dengan Prinsip Akuntansi Berterima Umum dan dalam mengadakan pertanggungjawaban manajemen.

c. Penggunaan harta/aktiva diberikan atas persetujuan manajemen.

d. Jumlah aktiva yang terdapat dalam laporan keuangan sesuai dengan kenyataan yang ada.

Untuk dapat mencapai tujuan pengendalian akuntansi, suatu sistem harus mempunyai enam prinsip dasar yaitu pemisahan fungsi, prosedur pemberian wewenang, prosedur dokumentasi, prosedur pencatatan dan akuntansi, pengawasan fisik atas aktiva dan catatan akuntansi, pemeriksaan intern secara bebas.

Pengendalian intern akuntansi yang baik tentunya akan menjamin kekayaan para investor dan kreditur yang ditanamkan dalam perusahaan dan akan menghasilkan laporan keuangan yang dapat dipercaya.

2. Pengendalian intern administratif (internal administrative control)

Pengendalian intern administratif meliputi struktur organisasi, metode dan ukuran-ukuran yang dikoordinasikan terutama untuk mendorong efisiensi dan dipatuhinya kebijakan manajemen. Pengendalian intern administrasi 
berhubungan dengan proses

pengambilan keputusan dan mengarah pada otorisasi transaksi. Tujuan pengendalian administrasi diutamakan pada pencapaian tujuan operasional seperti hubungan masyarakat, efisiensi operasi atau pabrik, efektivitas operasi dan efektivitas manajemen. Pengendalian intern administrasi mempunyai pengaruh langsung terhadap pengendalian akuntansi karena merupakan titik awal untuk menciptakan pengendalian akuntansi, meskipun pengaruhnya terhadap keandalan laporan keuangan kecil.

Unsur-unsur pokok pengendalian intern menurut Mulyadi (2016:164) adalah sebagai berikut:

1. Struktur organisasi yang jawab fungsional dalam organisasi didasarkan pada prinsip-prinsip sebagai

berikut:

a. Harus dipisahkan fungsifungsi operasi dan penyimpanan dari fungsi akuntansi.

b. Suatu fungsi tidak boleh diberi tanggung jawab penuh untuk melaksanakan semua tahap transaksi.

Menurut Hartadi (2018:16), ada empat hal yang harus diperhatikan dalam pemisahan tanggung jawab, yaitu

a. Bagian

penyimpanan aktiva

harus dipisahkan

dari bagian

akuntansi.

b. Bagian yang melakukan

otorisasi harus

dipisahkan dengan

bagian yang menyimpan.

c. Adanya pemisahan

fungsi operasi dan

pencatatan. d. Pemisahan dalam

bagian

pencatatan/akunta

nsi.

Struktur organisasi yang baik adalah yang sederhana dan fleksibel, dalam arti dapat memisahkan tanggung jawab secara jelas dan dapat mengikuti perkembangan perusahaan bila ada perkembangan dan perluasan sehingga tidak mengganggu struktur yang telah ada.

2. Sistem wewenang dan prosedur pencatatan yang memberikan perlindungan yang cukup terhadap kekayaan, utang, pendapatan dan biaya

Dalam suatu organisasi setiap transaksi hanya terjadi atas dasar otorisasi dari pejabat yang berwenang untuk menyetujui terjadinya transaksi

memisahkanteangutngjkekakafuemgsiiounaldsdenrastefas Struktur organisasi perlu dibuat sistem yang mengatur pembagian wewenang untuk otorisasi atas terlaksananya setiap transaksi. Sistem otorisasi diharapkan dapat menjamin dihasilkannya dokumen pembukuan yang dapat dipercaya, sehingga akan menjadi masukan yang dapat dipercaya bagi proses akuntansi. Prosedur pencatatan yang baik akan menghasilkan informasi yang teliti dan dapat dipercaya mengenai kekayaan, utang, pendapatan dan biaya suatu organisasi.

3. Praktik yang sehat dalam melaksanakan tugas dan fungsi setiap unit organisasi.

Praktik yang sehat sering diartikan sebagai pelaksanaan aturanaturan yang telah ditentukan dalam lingkungan perusahaan. Praktik yang sehat juga diartikan sebagai alat taktis untuk penerapan suatu rencana yaitu suatu hal yang harus dilaksanakan agar rencana yang telah dibuat dapat dicapai.

Pembagian tanggung jawab fungsional dan sistem wewenang dan prosedur pencatatan yang telah ditetapkan tidak akan terlaksana dengan baik jika tidak diciptakan cara-cara 
untuk menjamin praktik yang sehat dalam pelaksanaannya.

Cara-cara yang ditempuh oleh perusahaan dalam menciptakan praktik yang sehat menurut Mulyadi (2016:317), yaitu:

a. Penggunaan formulir bernomor urut tercetak yang pemakaiannya harus dipertanggungjawabkan oleh bagian yang berwenang.

b. Pemeriksaan mendadak.

c. Setiap transaksi tidak boleh dilaksanakan dari awal sampai akhir oleh satu orang atau satu unit organisasi tanpa ada campur dari orang atau unit organisasi lain.

d. Perputaran jabatan.

e. Keharusan pengambilan cuti bagi karyawan yang berhak.

f. Pembentukan unit organisasi yang bertugas untuk mengecek efektivitas unsurunsur pengendalian intern yang lain.

g. Secara periodik dilakukan pencocokan fisik antara kekayaan dengan catatan.

4. Karyawan yang mutunya sesuai dengan tanggung jawabnya Diantara unsur sistem pengendalian intern yang lain, unsur karyawan yang mutunya sesuai dengan tanggung jawabnya memegang peranan penting sebab pelaksana dari sistem pengendalian intern ini nantinya adalah karyawan, jadi jika perusahaan memiliki karyawan yang kompeten dan jujur, unsur pengendalian intern yang lain dapat dikurangi sampai batas yang minimum. Perusahaan itu dalam penarikan tenaga kerja harus diarahkan agar mendapat calon pegawai yang memadai yaitu melalui prosedur pengujian yang ketat, pendidikan dan latihan yang cukup serta pengukuran prestasi atas tanggung jawab yang diberikan.

\section{Pengertian Persediaan}

Persediaan merupakan barang-barang yang dibeli oleh perusahaan dengan tujuan untuk dijual kembali. Persediaan menjadi bagian yang penting bagi perusahaan, baik untuk persediaan dagang maupun manufaktur.

Terdapat beberapa definisi persediaan yang dikemukakan oleh para ahli, diantaranyaadalah sebagai berikut:

1. Rangkuti (2018:25), persediaan adalah suatu aktiva yang meliputi barangbarang milik perusahaan dengan maksud untuk dijual dalam suatu periode usaha tertentu, atau persediaan barang-barang yang masih dalam proses/pengerjaan produksi, ataupun persediaan bahan baku yang menunggu penggunaannya dalam suatu proses produksi.

2 Soemarso (2018:19), persediaan barang dagangan adalah barang-barang yang dimiliki perusahaan untuk dijual kembali.

Pada perusahaan dagang, persediaan merupakan elemen yang sangat penting karena tanpa persediaan suatu perusahaan dagang tidak dapat beroperasi. Jumlah persediaan yang tinggi dapat membuat perusahaan dapat memenuhi kebutuhan konsumennya, namun jumlah persediaan yang tinggi dapat menghambat kegiatan perusahaan karena sebagian besar dana perusahaan tertanam di persediaan dan tidak dapat diputarkan lagi, sebaliknya jumlah persediaan yang terlalu kecil membuat perusahaan tidak dapat memenuhi permintaan konsumen.

Untuk itu persediaan sebaliknya ditetapkan dalam jumlah optimum, tidak terlalu tinggi dan tidak terlalu kecil sebab besarnya persediaan dapat mempengaruhi tingkat keuntungan yang diperoleh perusahaan. Persediaan biasanya dinilai pada harga terendah antara harga perolehan dengan harga pasar atau nilai yang diharapkan dapat direalisasikan, cara 
penilaian persediaan harus

diungkapkan dalam catatan atas laporan keuangan.

\section{Komponen Sistem Pengendalian Intern}

Menurut AICPA (American Institute of Certified Public Accountants) dalam ASA (Statement on Auditing Standards) No. 78 yang terdapat dalam Standar Profesi Akuntan Publik tahun 2013 menyatakan bahwa komponen pengendalian internal terdiri dari :

1. Lingkungan Pengendalian

Lingkungan pengendalian

internal adalah hal yang mendasar dalam komponen pengendalian internal.

diketahui bahwa efektifitas pengendalian dalam suatu organisasi terletak pada sikap manajemen. Lingkungan pengendalian merupakan landasan untuk semua unsur pengendalian internal lainnya yang membentuk disiplin dan struktur dalam organisasi.

Menurut Hartadi

(2018:28), lingkungan pengendalian memiliki beberapa elemen penting diantaranya yaitu :

a) Falsafah dan gaya manajemen operasi, seperangkat parameter bagi perusahaan dan karyawan. Falsafah merupakan apa yang seharusnya dikerjakan dan apa yang tidak dikerjakan oleh perusahaan. Manajemen, melalui aktivitasnya, memberikan tanda yang jelas kepada pegawai tentang pentingnya pengendalian. Gaya operasi mencerminkan ide manajer tentang bagaimana operasi suatu perusahaan harus dilakukan. b) Struktur organisasi, biasanya digambarkan dalam suatu bagan organisasi. Bagan organisasi ini menunjukkan garis arus komunikasi dalam organisasi

c) Komite audit, dewan komisaris yang efektif adalah yang independen dari manajemen dan anggota-anggotanya aktif menilai aktivitas manajemen. Komite audit biasanya dibebani tanggung jawab mengenai laporan keuangan, mencakup struktur pengendalian intern, dan ketaatan terhadap peraturan dan undangundang. Komite audit harus memelihara komunikasi langsung yang terus menerus, baik antara dewan komisaris dengan auditor

Lingkungan peingendalliamtandiurn dariktindaklan, kelaijakan, prose pengendalian intern menjadi lebih efektif.

d) Penetapan wewenang dan tanggung jawab, disamping aspek komunikasi informal, metode komunikasi formal mengenai wewenang dan tanggung jawab dan masalah sejenis yang berkaitan dengan pengendalian juga sama pentingnya. Hal ini mencakup cara-cara seperti memo dari manajemen tentang pentingnya pengendalian dan masalah yang berkaitan dengan pengendalian, organisasi formal dan rencana operasi, deskripsi tugas pegawai dan kebijakan terkait, dan dokumen kebijakan yang menggambarkan perilaku pegawai seperti perbedaan kepentingan dan kode etik perilaku formal.

e) Metode pengawasan manajemen, metode yang digunakan manajemen untuk memantau aktivitas setiap fungsi dan anggota organisasi. Menurut Bodnar dan Hopwood (2018:178), metode-metode pengendalian manajemen terdiri dari teknik-teknik yang digunakan oleh manajemen untuk menyampaikan instruksi dan tujuan-tujuan operasi kepada bawahan dan untuk 
mengevaluasi hasil-hasilnya.

f) Fungsi audit internal, dibuat dalam satuan usaha untuk memantau efektivitas kebijakan dan prosedur lain yang berkaitan dengan pengendalian.

direksi dan komisaris. Praktek dan kebijakan karyawan, tujuan pengendalian internal dapat dicapai melalui serangkaian tindakan manusia dalam organisasi, maka anggota organisasi merupakan elemen yang paling penting dalam struktur pengawasan intern. Tujuan pengendalian internal harus dipandang relevan dengan individu yang menjalankan pengendalian tersebut. Oleh karena pentingnya perusahaan memiliki pegawai yang jujur dan kompeten, maka perusahaan perlu memiliki kebijakan dan prosedur yang baik dalam

penerimaan

g) Pengaruh ekstern adalah pengaruh yang ditetapkan dan dilakukan oleh pihak luar suatu perusahaan, yang mempengaruhi suatu operasi dan praktek perusahaan. Hal ini meliputi pemantauan dan kepatuhan terhadap persyaratan yang ditetapkan badan legislatif dan instansi yang mengatur. Pengaruh ekstern biasanya merupakan wewenang diluar perusahaan. Pengaruh ini dapat meningkatkan kesadaran dan sikap manajemen terhadap perilaku dan pelaporan operasi perusahaan, serta dapat juga mendesak manajemen untuk menetapkan kebijakan dan prosedur pengendalian internal.

\section{Penilaian Resiko Menurut Hartadi} (2018:29), perusahaan harus melakukan penilaian resiko (risk assessment) untuk mengindentifikasi, menganalisis, dan mengelola resiko yang berkaitan dengan pelaporan keuangan. Penilaian resiko manajemen untuk tujuan pelaporan keuangan dan desain serta implementasi aktivitas pengendalian yang ditujukan untuk mengurangi resiko tersebut pada tingkat

minimum

\section{Informasi dan Komunikasi}

Menurut Mulyadi (2016:179-180), sistem akuntans1 akuntansi yang efektil adalah sistem akuntansi yang dapat memberikan keyakinan yang memadai bahwa transaksi dicatat atau terjadi adalah :
a. Sah
b. Telah diotorisasi
c. Telah dicatat
d. Telah dinilai secara wajar
e. Telah digolongkan secara wajar

f. Telah dicatat dalam periode seharusnya

g. Telah dimasukkan ke dalam buku pembantu dan telah diringkas dengan benar

Komunikasi menyangkut penyampaian informasi kepada semua

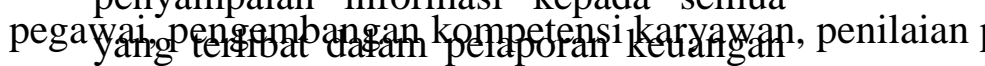
agar mereka memahami bagaimana aktivitasnya berhubungan dengan pekerjaan orang lain, baik didalam organisasi maupun diluar organisasi. Menurut Mulyadi (2016:180), pedoman kebijakan, pedoman akuntansi dan pelaporan keuangan, daftar akuntansi dan memo juga merupakan bagian dari komponen informasi dan komunikasi dalam struktur pengendalian internal.

3. Pengawasan

$$
\text { Pemantauan (monitoring) }
$$

adalah proses penilaian kualitas kinerja struktur pengendalian internal secara periodik dan terus-menerus. Pemantauan dilaksanakan oleh orang yang semestinya melakukan pekerjaan tersebut, baik pada tahap desain maupun pengoperasian pengendalian pada waktu yang tepat. Tujuannya adalah untuk menentukan apakah pengawasan intern telah beroperasi sebagaimana yang telah diperbaiki sesuai dengan perubahan keadaan. Pemantauan dapat dilakukan oleh suatu bagian khusus yang disebut dengan bagian pemeriksaan intern (audit internal).

4. Aktivitas Pengendalian 
Hartadi (2018:32), aktivitas pengendalian (control activity) adalah berbagai kebijakan dan prosedur yang digunakan untuk memastikan bahwa tindakan yang tepat telah dilakukan untuk menangani berbagai resiko yang telah diidentifikasi perusahaan.

\section{METODE PENELITIAN Jenis Penelitian}

Metode pendekatan penelitian yang penulis gunakan dalam penelitian ini adalah metode kualitatif, yaitu penelitian yang menguraikan sifat-sifat dan keadaan sebenarnya dari suatu objek penelitian.Pengertian metode kualitatif adalah metode yang digunakan untuk menggambarkan atau menganalisis suatu hasil penelitian tetapi tidak digunakan membuat kesimpulan yang lebih luas.

\section{Teknik Pengumpulan Data}

Adapun teknik pengumpulan data yang dilakukan oleh penulis,untuk menganalisis sistem pengendalian intern persediaan pada koperasi tirta lestari dengan beberapa cara yaitu :

a. Pengamatan (Observasi)

Yaitu pengumpulan data yang dilakukan dengan mengamati secara langsung pada objek yang diteliti untuk memperoleh gambaran yang lebih jelas tentang permasalahan yang akan dibahas. Wawancara (interview)

Yaitu mengumpulkan informasi dengan media tanya jawab secara langsung dengan responden.

b. Dokumentasi

Yaitu teknik mengumpulkan, meneliti, mempelajari dokumen, catatan dan laporan- laporan yang berhubungan dengan masalah yang akan diteliti dari dokumendokumen yang dimiliki oleh perusahaan.

\section{Teknik Analisis Data}

Metode analisis data yang digunakan oleh

penulis

1. Reduksi Data

Yakni merangkum, memilih hal-hal pokok. Memfokuskan pada hal-hal yang penting pada penelitian yang hanya maslah terkait Pada Sistem pengendalian intern persediaan pada koperasi tirta lestari Banjarbaru

2. Penyajian Data

Adalah pengumpulan informasi yang terkait atas Sistem pengendalian intern persediaan pada koperasi tirta lestari Banjarbaru

3. Verifikasi /Kesimpulan

Adalah tahapan terakhir dalam proses analisis data.Pada bagian ini penulis mengutarakan kesimpulan dari data-data yang diperoleh, atas judul penelitian yakni Sistem pengendalian intern persediaan pada koperasi tirta lestari Banjarbaru.

\section{HASIL PENELITIAN}

Koperasi Tirta Lestari Banjarbaru adalah sebuah koperasi yang bergerak dibidang usaha perdagangan dan jasa. Koperasi ini beranggotakan sebanyak 263 orang. Koperasi ini dibentuk pada tanggal 09 November 1998 dengan akta pendirian Nomor 1502.b/BH/IX/9-9-1998 yang beralamatkan di Jalan P. Hidayatullah No. 24 RT. 003 RW. 002 Kelurahan Komet Banjarbaru Utara.

\section{Komponen Sistem Persediaan Koperasi Tirta Lestari Banjarbaru}

Peraturan terhadap komponen sistem persediaan barang dagangan yang ada pada Koperasi Tirta Lestari Banjarbaru belum ada untuk dapat mengamankan persediaan barang dagangan dari tindakan pencurian, penyelewengan, dan kerusakan yang dilakukan oleh karyawan Koperasi Tirta Lestari Banjarbaru. 


\section{a. Sumber Daya Manusia}

Sumber daya manusia terhadap komponen sistem persediaan di Koperasi Tirta Lestari Banjarbaru masih terdapat kelemahannya meliputi:

1) Belum adanya karyawan yang ditugaskan khusus untuk menangani atau mengkontrol keluarmasuknya barang dari gudang, setiap karyawan bisa dengan mudah mengambil kesediaan tanpa ada perintah khusus.

2) Melakukan stock opname hanya saat ada barang masuk dan barang yang keluar saja.

3) Terjadi perangkapan jabatan oleh bagian pembelian yang bertugas melakukan pemesanan dan penerimaan barang yang dilakukan oleh 1 orang yang sama.

\section{b. Peralatan}

Peralatan yang

dimiliki oleh pihak Koperasi

Tirta Lestari Banjarbaru meliputi komputer yang digunakan untuk membuat pencatatan terhadap persediaan barang keluar dan masuk. Catatan akuntansi yang digunakan untuk mencatat transaksi persediaan pada Koperasi Tirta Lestari Banjarbaru adalah kartu persediaan, dimana kartu persediaan ini digunakan untuk mencatat harga pokok persediaan yang dibeli.

\section{c. Prosedur}

Prosedur persediaan barang dagangan pada Koperasi Tirta Lestari Banjarbaru meliputi:
1) Fungsi
pembelian
mengajukan permintaan

pembelian kepada pemasok, menerima, memeriksa, mengotorisasi dan melakukan pencatatan mutasi jumlah persediaan berdasarkan faktur penjualan.

2) Fungsi akuntansi menerima faktur penjualan dan mencatat transaksi pembelian.

\section{d. Data}

1) Surat order penjualan, dokumen ini merupakan formulir yang diisi oleh fungsi gudang atau fungsi pemakai barang (bagian pemesanan) untuk meminta fungsi pembelian melakukan pembelian barang dengan jenis, jumlah, dan mutu. Adapun dokumen tersebut yang telah dirancang oleh Koperasi Tirta Lestari Banjarbaru dalam sistem pengendalian intern persediaan yang dilakukan dapat dilihat pada tabel berikut:

Tabel 2

Koperasi Tirta Lestari

Banjarbaru Surat Order Penjualan

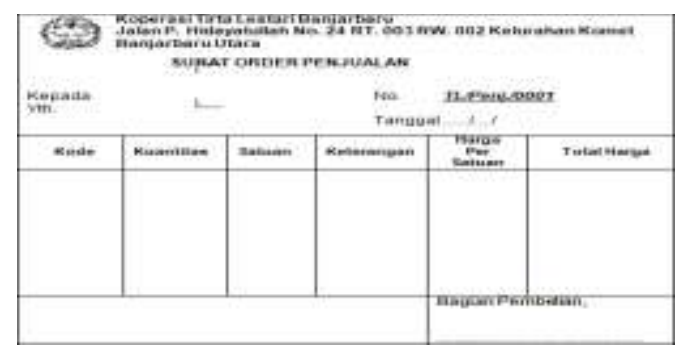

Sumber : Koperasi Tirta Lestari Banjarbaru

Faktur penjualan merupakan formulir yang diisi oleh bagian pembelian untuk menunjukkan bahwa harga, perkalian dan penjumlahan dalam faktur sudah betul, dan barang yang diterimanya sesuai dengan yang dipesan. Adapun dokumen tersebut pada Koperasi Tirta Lestari Banjarbaru dalam sistem pengendalian intern persediaan yang dilakukan dapat dilihat pada tabel berikut: 
Tabel 3

Koperasi Tirta

Lestari Banjarbaru

Faktur Penjualan

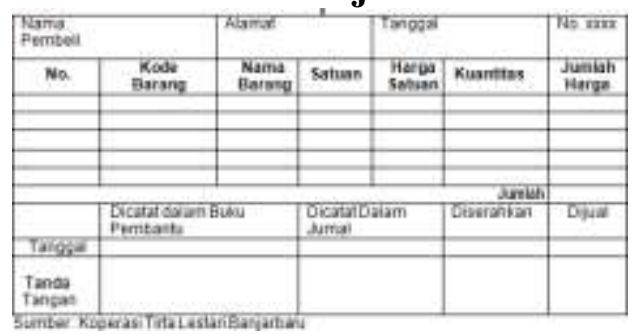

2. Komponen Pengendalian Intern Persediaan Koperasi Tirta Lestari Banjarbaru

a. Lingkungan Pengendalian

Penetapan wewenang dan tanggung jawab dalam pengendalian intern persediaan belum cukup baik dilakukan oleh Koperasi Tirta Lestari Banjarbaru, dikarenakan tidak adanya pemisahan fungsi-fungsi wewenang dan tanggung jawab masing-masing. Koperasi Tirta Lestari Banjarbaru belum memiliki kebijakan dan prosedur penilaian karyawan yang cukup baik. Tidak adanya penerapan kebijakan perekrutan, pelatihan dan pemberian rewards bagi yang berprestasi, sehingga belum dapat membentuk kualitas karyawan yang jujur, terampil dan memiliki loyalitas terhadap Koperasi Tirta Lestari Banjarbaru.

b. Penilaian Resiko

Penilaian resiko yang dilakukan oleh Koperasi Tirta Lestari Banjarbaru agar penyajian informasi persediaan barang dagangan adalah wajar dan tepat waktu belum memadai. Tidak adanya penilaian yang dilakukan yaitu dengan menjaga mutu barang yang tersimpan dalam gudang, terlebih pada barang dagangan yang mudah rusak/cacat. Selain itu, pemeriksaan kondisi barang tidak dilakukan setiap hari untuk dapat menghindari barang darikerusakan.

c. Pengendalian Kegiatan

1) Koperasi Tirta Lestari Banjarbaru belum mengadakan pemisahan tugas untuk menangani setiap transaksi atau kegiatan yang terjadi khususnya dengan persediaan, sehingga belum terciptanya pengendalian intern dalam Koperasi Tirta Lestari Banjarbaru. Pemisahan tugas tidak dilakukan mulai dari perencanaan, pengelolaan, penerimaan, penyimpanan dan pengeluaran.

2) Tidak adanya surat order pembelian yang bertujuan sebagai surat atau dokumen pemesanan barang kepada pemasok

\section{d. Komunikasi Informasi}

Sistem informasi dan komunikasi oleh Koperasi Tirta Lestari Banjarbaru belum optimal atas dasar penyusunan prosedur yang belum jelas dalam Koperasi Tirta Lestari Banjarbaru, termasuk dalam prosedur pengawasan persediaan yang tidak melibatkan beberapa fungsi terkait, dokumen dan catatan yang diperlukan tidak harus didasarkan atas laporan sumber yang dilampiri dengan dokumen pendukung yang lengkap dan diotorisasi oleh pihak yang berwenang.

\section{e. Pengawasan / Pemantauan}

Pengawasan terhadap persediaan barang dagang tidak diawasi oleh bagian yang lebih tinggi posisinya dan secara keseluruhan, kegiatan operasional hanya diawasi oleh manager koperasi ini. Aktivitas ini belum cukup baik dalam mendukung terciptanya pengendalian intern yang memadai dalam Koperasi 
Tirta Lestari Banjarbaru.

\section{PEMBAHASAN}

Sistem Pengendalian Intern Persediaan Yang Selama Ini Dilakukan Oleh Koperasi Tirta Lestari Banjarbaru

Kebijakan, teknik prosedur, alat-alat fisik, dokumentasi orangorang dengan berinteraksi satu sama lain yang diarahkan untuk melindungi harta dan menjamin ketelitian data akuntansi yang telah dirancang oleh pihak Koperasi Tirta Lestari Banjarbaru dalam sistem pengendalian intern persediaan adalah sebagai berikut:

1. Struktur organisasi yang memisahkan tanggung jawab fungsional secara tegas

Salah satu unsur pokok sistem pengendalian intern mengharuskan adanya pemisahan fungsi operasi, fungsi penyimpanan dan fungsi akuntansi. Dalam prosedur pengadaan barang, fungsi akuntansi yang bertanggung jawab mencatat mutasi utang dan persediaan barang harus dipisahkan dari fungsi operasi yang melakukan transaksi pengadaan barang serta pemisahan fungsi gudang yang bertanggung jawab atas penyimpanan barang. Pada Koperasi Tirta Lestari Banjarbaru pemisahan fungsi dalam pelaksanaan prosedur pengadaan barang yang telah dirancang dan belum dilaksanakan dengan baik. Meskipun demikian pelimpahan tanggung jawab fungsi pembelian dan fungsi penyimpanan yang diserahkan pada satu orang dirasa kurang efektif karena jika kondisi demikian dibiarkan terus berlanjut akan memicu dilakukannya kecurangan.
Selain itu, pelaksana transaksi pengadaan barang didominasi oleh bagian gudang dari prosedur pemesanan sampai dengan penyimpanan sekaligus pengelola kartu persediaan kesemuanya menjadi tanggung jawab bagian gudang. Selama ini kondisi yang sedemikian belum memicu terjadinya kecurangan tetapi bersamaan dengan pengembangan usaha Koperasi Tirta Lestari Banjarbaru kondisi yang seperti itu berpotensi untuk terjadi kecurangan. Untuk lebih jelasnya, bentuk struktur organisasi yang dimiliki Koperasi Tirta Lestari Banjarbaru selama ini adalah sebagai berikut:

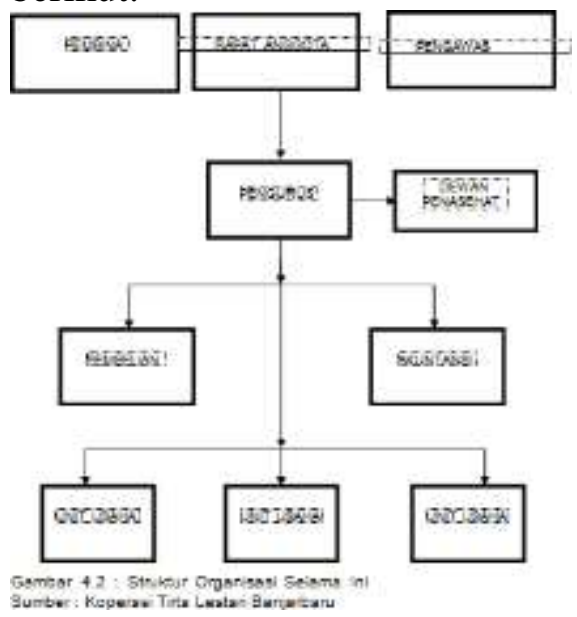

2. Sistem wewenang dan prosedur pencatatan yang memberikan perlindungan yang cukup terhadap kekayaan, utang, pendapatan dan biaya

Pada Koperasi Tirta Lestari Banjarbaru telah dilakukan otorisasi terhadap dokumen yang digunakan dalam prosedur pembelian barang oleh bagian yang berwenang. Dokumen tersebut antara lain faktur penjualan yang diterima dari pemasok dan bukti pengeluaran kas. Sebagai bukti telah diterimanya barang dari pemasok, fungsi pembelian yang sekaligus merangkap sebagai fungsi penerimaan membubuhkan tanda tangan otorisasi 
pada faktur penjualan dari pemasok yang sekaligus berfungsi sebagai laporan penerimaan barang. Dokumen ini nantinya dikirim oleh fungsi pembelian ke fungsi akuntansi sebagai bukti bahwa barang yang diterima dari pemasok telah diperiksa oleh fungsi pembelian, sehingga fungsi akuntansi dapat segera mencatat kewajiban yang timbul dari transaksi pembelian dan bertambahnya persediaan barang.

Pembelian barang dagangan akan menimbulkan utang usaha jika dilakukan dengan kredit dan akan menimbulkan pengeluaran kas jika dilakukan secara tunai. Dokumen pengeluaran kas yang lebih dikenal dengan kwitansi pada Koperasi Tirta Lestari Banjarbaru dikeluarkan oleh kasir untuk membayar transaksi pembelian secara tunai maupun untuk membayar utang usaha atas transaksi pembelian yang terjadi. Dokumen ini sebelum diserahkan kepada pemasok sebelumnya telah diotorisasi oleh kasir sebagai bukti bahwa dokumen ini benar-benar dikeluarkan oleh kasir. Dokumen ini selanjutnya diserahkan kepada bagian pembelian dan akuntansi untuk dilakukan pencatatan terhadap mutasi utang dan persediaan.

Pada Koperasi Tirta Lestari Banjarbaru bagian pembelian tidak mengeluarkan surat order pembelian yang berfungsi sebagai pemesanan barang kepada pemasok, tetapi pemasok sendiri yang datang ke bagian pembelian dan membuat order penjualan. Selama ini hal yang demikian tidak menjadikan masalah tetapi jika dibiarkan berlanjut akan menjadikan masalah bagi koperasi sendiri. Masalah itu dapat ditimbulkan karena order yang tidak sesuai dengan pesanan bagian pembelian karena bukan bagian pembelian sendiri yang membuat, selain itu pencatatan order yang dilakukan oleh pemasok tidak dilakukan pengecekan ulang oleh bagian pembelian sehingga pemasok bisa saja mencantumkan jumlah yang lebih besar dari yang diminta oleh bagian pembelian dan bagian pembelian tidak dapat menuntut jika hal itu dilakukan karena tidak memiliki surat order pembelian sendiri yang bisa menjadi bukti bahwa bagian pembelian melakukan pembelian dalam jumlah tertentu dan pencatatan persediaan yang dilakukan menggunakan metode fisik yaitu metode pencatatan persediaan yang tidak mengikuti mutasi persediaan sehingga untuk mengetahui jumlah persediaan pada suatu saat tertentu harus diadakan perhitungan fisik atas persediaan barang. Pada koperasi ini metode yang digunakan dalam pencatatan persediaan barang menggunakan metode rata - rata tertimbang, yang mana pengeluaran barang secara acak dan harga pokok barang yang sudah digunakan maupun yang masih ada ditentukan dengan cara dicari rata - rata.Adapun bentuk metode penghitungan pencatatan yang dilakukan dengan metode rata-rata tertimbang. Tidak dibuatnya surat order pembelian ini juga berdampak koperasi tidak dapat melayani pembeli jika barang tertentu telah habis tetapi pemasok belum melakukan kunjungan sehingga bagian pembelian harus mengambil barang dari pemasok lain yang melakukan kunjungan saat itu dengan resiko harga barang yang terkadang lebih mahal dari pemasok yang biasanya. Adapun bagan alur dalam sistem pengendalian intern persediaan yang telah dirancang oleh Koperasi Tirta Lestari Banjarbaru dapat dilihat pada Gambar 4.3 berikut ini: 


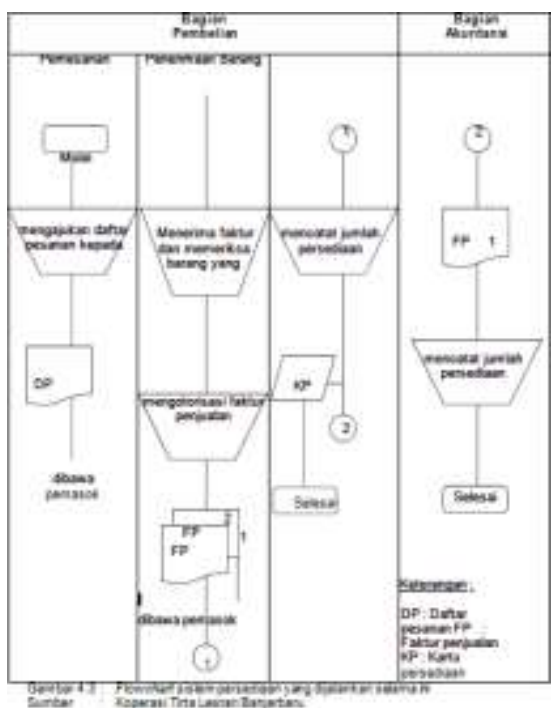

Deskripsi bagan alur yang dijalankan selama ini oleh Koperasi Tirta Lestari Banjarbaru, yaitu:

1. Bagian pembelian mengajukan dan membuat daftar pesanan permintaan pembelian barang kepada pemasok.

2. Bagian pembelian menerima dan memeriksa jumlah dan jenis barang yang dikirim oleh pemasok.

3. Bagian pembelian mengotorisasi faktur penjualan yang diterima dari pemasok.

4. Bagian pembelian melakukan pencatatan mutasi jumlah persediaan berdasarkan faktur penjualan yang diterima dari pemasok.

5. Bagian akuntansi menerima faktur penjualan dari pemasok dan mencatat transaksi pembelian serta mencatat jumlah persediaan.

Bentuk dokumen dalam flowchart dapat ditampilkan sebagai berikut:

Tabel 4

Koperasi Tirta Lestari Banjarbaru
Daftar Pesanan

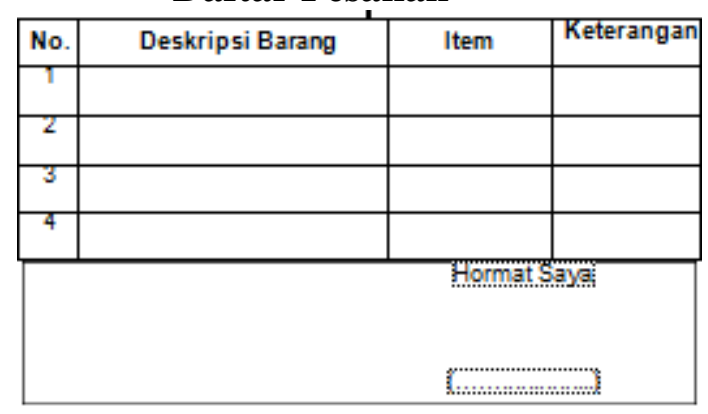

Sumber : Koperasi Tirta Lestari Banjarbaru

Tabel 5

Koperasi Tirta Lestari

Banjarbaru Faktur

Penjualan

\begin{tabular}{|c|c|c|c|c|c|c|}
\hline \multicolumn{2}{|l|}{$\begin{array}{l}\text { Nama } \\
\text { Pembeli }\end{array}$} & \multicolumn{2}{|l|}{ Alamat } & \multicolumn{2}{|l|}{ | |anggal } & \multirow{2}{*}{$\begin{array}{l}\text { No. } X X X X X \\
\text { Jumlah } \\
\text { Harga }\end{array}$} \\
\hline No. & $\begin{array}{c}\text { Kode } \\
\text { Barang }\end{array}$ & $\begin{array}{l}\text { Nama } \\
\text { Barang }\end{array}$ & Satuan & $\begin{array}{l}\text { Harga } \\
\text { Satuan }\end{array}$ & Kuantitas & \\
\hline & & & & & & \\
\hline & & & & & & \\
\hline & & & & & & \\
\hline & & & & & & \\
\hline & & & & & Jamla & \\
\hline & $\begin{array}{l}\text { Dicatat dal: } \\
\text { Pembantu }\end{array}$ & & $\begin{array}{l}\text { Dicatat L } \\
\text { Jurnal }\end{array}$ & & Diserahkan & Dijual \\
\hline Tangga & & & & & & \\
\hline $\begin{array}{l}\text { Tanda } \\
\text { Tangan }\end{array}$ & & & & & & \\
\hline
\end{tabular}

Tabel 6

Koperasi Tirta Lestari

Banjarbaru Kartu Persediaan

\begin{tabular}{|c|c|c|c|c|c|c|}
\hline & & & RTU PER & SEDIAAN & & \\
\hline No. Kode & & & & & & \\
\hline Nama Barar & & & & Lokasi & & \\
\hline Spesifikasi & & & & Minimum & & \\
\hline DITE & & & DIPAF & & & $5 A$ \\
\hline TII & Kuantritas & Tgा & No. Bukt & Kuantrias & Kuantitas & Keteranga \\
\hline & & & & & & \\
\hline & & & & & & \\
\hline & & & & & & \\
\hline & & & & & & \\
\hline & & & & & & \\
\hline & & & & & & \\
\hline & & & & & & \\
\hline & & & & & & \\
\hline & & & & & & \\
\hline
\end{tabular}

3. Praktik yang sehat dalam melaksanakan tugas dan fungsi setiap unit organisasi

JIEB, Jilid 7, No 1, Maret 2021 ISSN Online 2615-2134 


\section{Pada Koperasi Tirta}

Lestari Banjarbaru perputaran jabatan belum dilaksanakan, setiap karyawan menduduki posisi yang sama dari tahun ke tahun. Hal ini dilakukan karena spesifikasi keahlian yang berbeda dari masing-masing karyawan. Jika dilakukan perputaran jabatan dimungkinkan tidak efektif karena karyawan perlu beradaptasi lagi dengan tanggung jawab yang baru dan masing-masing karyawan membutuhkan waktu yang berbeda-beda untuk dapat beradaptasi dengan tanggung jawab barunya sehingga akan berpengaruh terhadap operasional koperasi. Tetapi di lain pihak, kondisi yang demikian menunjukkan masih rendahnya tingkat independensi karyawan dalam melaksanakan tugas sehingga diperlukan pelatihan yang cukup bagi karyawan.

Tidak ada keharusan pengambilan cuti bagi karyawan Koperasi Tirta Lestari Banjarbaru, jika ada karyawan yang berhalangan hadir diharapkan meminta ijin kepada Ketua Koperasi, sehingga ada karyawan lain yang menggantikan tugasnya selama karyawan tersebut tidak dapat hadir. Praktik seperti ini tidak berlaku bagi bagian akuntansi karena tidak semua karyawan memahami tanggung jawab dari bagian tersebut.

4. Karyawan yang mutunya sesuai dengan tanggung jawabnya Pada Koperasi Tirta Lestari Banjarbaru penarikan

Karyawan diluar anggota koperasi dilakukan melalui seleksi bukan atas dasar hubungan kekeluargaan, selain itu sebelum dilakukan penerimaan karyawan baru terlebih dahulu dilakukan analisa jabatan dan persyaratan yang harus dipenuhi oleh calon karyawan yang akan menduduki jabatan tersebut. Hal ini dilakukan agar karyawan yang nantinya diterima benar-benar kompeten. Selain itu Koperasi Tirta Lestari Banjarbaru juga memberikan pelatihan kepada karyawan sesuai dengan tuntutan pekerjaannya.

Pada Koperasi Tirta Lestari Banjarbaru semua karyawan toko terlibat dalam proses penghitungan fisik persediaan, semua karyawan dituntut untuk teliti dan cermat saat melakukan penghitungan fisik persediaan. Karena dari keempat unsur pengendalian intern ini karyawan merupakan unsur paling menentukan karena sebaik apapun sistem yang dirancang tapi pelaksana dari sistem itu tidak mendukung hasilnya tidak akan maksimal.

\section{Sistem Pengendalian Intern Persediaan Yang Seharusnya Dilakukan Oleh Koperasi Tirta Lestari Banjarbaru}

Berdasarkan kekurangan yang ada pada Koperasi Tirta Lestari Banjarbaru terutama pada pengendalian intern atas persediaan, maka alternatif yang dapat diambil dalam merancang dan menyusun pengendalian intern atas persediaan yang seharusnya adalah sebagai berikut :

\section{Struktur organisasi yang memisahkan} tanggung jawab fungsional secara tegas

Salah satu unsur pokok pengendalian intern mengharuskan adanya pemisahan wewenang dan tanggung jawab. Dalam prosedur persediaan yang baik adalah memisahkan bagian pemesanan dengan bagian penerimaan barang. Pada Koperasi Tirta Lestari Banjarbaru seharusnya dilakukan pemisahan fungsi dalam pelaksanaan prosedur persediaan yang telah dilaksanakan. Pelimpahan akan tanggung 
jawab tersebut yang diserahkan tidak boleh pada satu orang karena kondisi demikian jika dibiarkan terus berlanjut akan memicu terjadinya kecurangan. Selama ini kondisi yang sedemikian belum memicu dilakukannya kecurangan tetapi bersamaan dengan pengembangan usaha Koperasi Tirta Lestari Banjarbaru kondisi seperti berpotensi untuk dilakukan kecurangan.

Berdasarkan uraian diatas, maka usulan bentuk struktur organisasi yang seharusnya dirancang dalam membentuk sistem pengendalian intern atas persediaan pada Koperasi Tirta Lestari Banjarbaru dapat dilihat pada gambar berikut

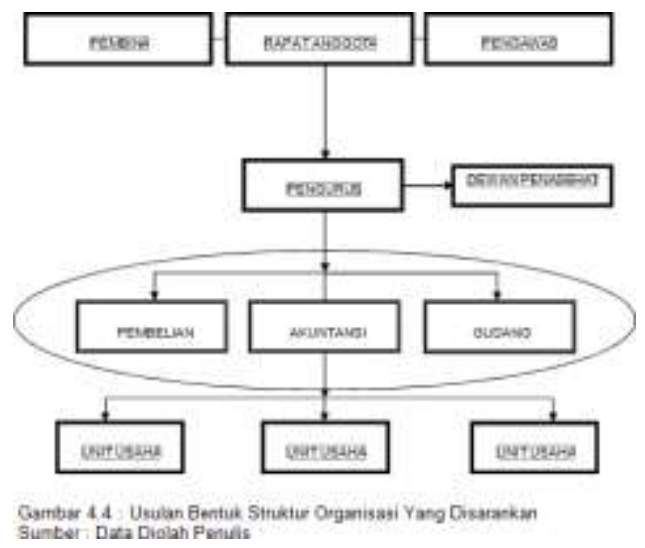

2. Sistem wewenang dan prosedur pencatatan yang memberikan perlindungan yang cukup terhadap kekayaan, utang, pendapatan dan biaya.

Metode

pencatatan

persediaan barang dagangan yang seharusnya digunakan oleh Koperasi Tirta Lestari Banjarbaru adalah metode buku/perpektual dengan sistem pencatatan FIFO dimana cara ini lebih baik untuk mencatat persediaan dan mencegah penyimpanan barang dagang yang terlalu dalam jumlah yang besar.
Dalam suatu Koperasi Tirta Lestari Banjarbaru, setiap transaksi yang terjadi harus berdasarkan atas otorisasi dari pejabat yang memiliki wewenang untuk menyetujui terjadinya transaksi tersebut. Sedangkan prosedur pencatatan yang baik akan menjamin data yang direkam dalam formulir dicatat dalam catatan akuntansi dengan tingkat ketelitian dan keandalan yang tinggi.

Hendaknya sistem otorisasi dan prosedur persediaan pada Koperasi Tirta Lestari Banjarbaru serta sistem pengendalian intern persediaan dengan uraian yang disarankan sebagai berikut :

a. Setiap pesanan maupun transaksi yang dilakukan yang diterima dicatat dan ditandatangani oleh pemasok, bagian yang menerima barang, bagian memesan barang, bagian pembelian dan bagian akuntansi atas kegiatan persediaan yang dilakukan.

b. Tanda terima dilaporkan kepada fungsi akuntansi sebagai laporan harian untuk dicatat dalam pembukuan.

c. Bagian yang melakukan pembelian hendaknya membuatkan surat permintaan pembelian untuk arsip fungsi yang meminta barang.

Sistem otorisasi dan prosedur pencatatan persediaan pada Koperasi Tirta Lestari Banjarbaru seharusnya menciptakan kegiatan untuk menunjang terwujudnya sistem pengendalian intern persediaan yang memadai. Hal ini diperlukan untuk menghindari kesalahan atau kecurangan yang mungkin terjadi disebabkan oleh faktor internal. Dalam melakukan pengelolaan persediaan pada Koperasi Tirta Lestari Banjarbaru seharusnya sistem otorisasi diatur sebagai berikut :

a. Pembuatan surat permintaan pembelian barang dibuat oleh bagian gudang dan disetujui oleh Pengurus Koperasi Tirta Lestari Banjarbaru.

b. Bagian penerimaan barang yang bertugas untuk menerima semua barang yang dibeli koperasi. Pada waktu menerima barang bagian ini harus melakukan perhitungan fisik atas 
barang-barang yang diterima baik dengan cara menghitung, menimbang, atau dengan caracara yang lain, disamping itu bagian penerimaan juga harus mengadakan pemeriksaan kualitas barang-barang yang diterima.

Berdasarkan usulan bentuk flowchart yang disarankan diatas, maka deskripsi tugas yang dijalankan adalah sebagai berikut:

a. Fungsi pembelian membuat dan mengotorisasi atas informasi mengenai harga barang, menentukan pemasok dan mengeluarkan surat order pembelian kepada pemasok yang dipilih.

b. Fungsi gudang mengajukan permintaan pembelian barang kepada bagian pembelian dan untuk menyimpan barang.

c. Fungsi akuntansi bertanggung jawab mencatat transaksi pembelian ke dalam

kartu persediaan
menyelenggarakan $\begin{array}{r}\text { dansip } \\ \text { dokumen sumber } \\ \text { catatan utang. }\end{array}$
flowchart yang disarankan oleh penulis tersebut diatas memiliki kelebihan yaitu transaksi pembelian yang dilakukan oleh pihak Koperasi Tirta Lestari Banjarbaru dapat dilaksanakan oleh fungsi gudang, pembelian dan akuntansi sehingga hal ini memungkinkan bagian-bagian yang terkait dalam persediaan barang dapat melakukan koreksi atas transaksi yang dilakukan.

Sedangkan usulan atas penambahan dokumen bentuk surat order pembelian yang penulis sarankan dapat dilihat pada tabel berikut ini:

Tabel 7 Koperasi Tirta Lestari

\section{Banjarbaru Usulan Dokumen Surat Order Pembelian Yang Disarankan}

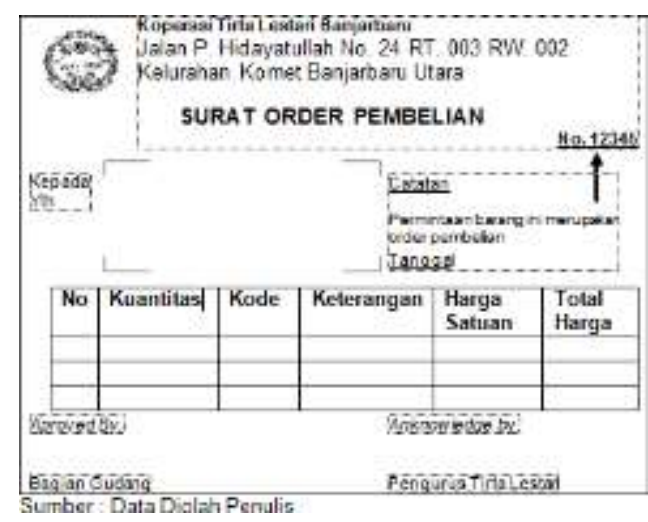

\section{Praktik yang sehat dalam melaksanakan tugas dan fungsi setiap unit organisasi.}

Praktik yang sehat dalam sistem persediaan merupakan suatu alat taktis untuk dapat berjalannya suatu sistem pengendalian intern atas pelaksanaan persediaan. Untuk itu dibuat peraturanperaturan dan prosedur yang jelas untuk setiap kegiatan. Dengan demikian terdapat persamaan persepsi untuk setiap tanggung jawab dan pelaksanaan sehingga dapat tercapai pengendalian intern yang baik. Praktik yang sehat hendaknya dijalankan dalam pelaksanaan persediaan pada Koperasi Tirta Lestari Banjarbaru adalah sebagai berikut :

a. Transaksi persediaan hendaknya dilakukan oleh berbagai fungsi yaitu bagian pembelian, bagian gudang dan akuntansi

b. Dilakukan pemeriksaan mendadak dan periodik seperti harian, mingguan maupun bulanan atas saldo persediaan barang yang dilakukan oleh bagian gudang.Hendaknya dilakukan rotasi perputaran bagian (job ratation) atas pekerjaan yang dilakukan selama ini.

c. Diberikan cuti kepada pekerja yang berhak menerima dan diberikan kompensasi berupa uang lembur maupun tambahan disaat 
melakukan pekerjaan yang membutuhkan tambahan waktu.

4. Karyawan yang mutunya sesuai dengan tanggung jawabnya

Karyawan yang

mempunyai integritas yang tinggi dalam arti mempunyai tingkat kecakapan yang sesuai dengan tanggung jawabnya sangat mendukung efektivitas sistem pengendalian intern persediaan yang dijalankan oleh Koperasi Tirta Lestari Banjarbaru. Upaya maupun tindakan yang dilakukan oleh manajemen Koperasi Tirta Lestari Banjarbaru untuk mendapatkan karyawan yang kompeten dan dapat dipercaya serta dalam rangka meningkatkan kecakapan karyawan sesuai dengan tanggung jawabnya, maka Koperasi Tirta Lestari Banjarbaru dapat menetapkan prosedur dan kebijakan sebagai berikut :

a. Proses penyeleksian calon karyawan khususnya bagian kasir berdasarkan persyaratan yang dituntut dan dibutuhkan oleh pekerjaannya. Dilakukan melalui beberapa tes tertulis dan wawancara.

b. Pemberlakuan masa percobaan kerja bagi karyawan baru selama 3 bulan hingga 6 bulan.

c. Adanya pengembangan pendidikan dan pelatihan bagi karyawan. Hal ini bisa ditempuh dengan bekerjasama dengan dinasdinas terkait seperti Dinas Tenaga Kerja maupun Balai Latihan Kerja setempat dan
Dinas Koperasi.

\section{PENUTUP \\ Kesimpulan}

Berdasarkan hasil penelitian dan pembahasan dibab sebelumnya, maka guna menjawab rumusan masalah dapat disimpulkan sebagai berikut :

1. Sistem pengendalian intern persediaan pada Koperasi Tirta Lestari Banjarbaru yang selama ini dijalankan masih belum optimal, dikarenakan adanya perangkapan tugas dan wewenang yang diemban oleh karyawan dan tidak ada dokumen pendukung yang lengkap dalam transaksi persediaan yang dilakukan sehingga hal ini dapat berpotensi untuk terjadinya kecurangan yang dapat dilakukan oleh karyawan.

2 Seharusnya sistem pengendalian intern persediaan yang dapat diterapkan oleh Koperasi Tirta Lestari Banjarbaru yaitu pemisahan fungsi dan sistem otorisasi yang diterapkan guna mengurangi kemungkinan terjadinya kecurangan, penambahan dokumen (surat order pembelian) guna diperoleh keyakinan memadai bahwa aktivitas persediaan barang telah benar dan sesuai sehingga dapat menjamin ketelitian data akuntansi dan keandalannya.

\section{Saran}

Berdasarkan kesimpulan diatas sebagai masukan bagi Koperasi Tirta Lestari Banjarbaru, maka penulis mengajukan beberapa saran masukan sebagai manajemen dapat membuat keputusan dalam mengurangi terjadinya kecurangan yang dapat dilakukan oleh karyawan sebagai berikut :

3. Dalam struktur organisasi sebaiknya pihak Koperasi Tirta Lestari Banjarbaru perlu melakukan penambahan dan pemisahan antara fungsi gudang, pembelian dan akuntansi dengan cara menempatkan salah satu karyawan sebagai bagian gudang yang berfungsi sebagai penerimaan dan pengendali persediaan barang yang dilakukan oleh pihak koperasi. 
4. Dalam sistem dan prosedur pencatatan akuntansi hendaknya Koperasi Tirta Lestari Banjarbaru menambahkan kekurangan dokumen yang belum lengkap dalam persediaan barang dagangan yaitu surat order pembelian sebagai bentuk bukti bahwa persediaan barang memang benar dan telah dilaksanakan.

5. Dalam praktik yang sehat seharusnya dilakukan job rotation dan pemeriksaan mendadak secara periodik terhadap persediaan barang dagangan yang dimiliki oleh Koperasi Tirta Lestari Banjarbaru.

6. Untuk menciptakan karyawan yang memiliki mutu sesuai tanggung jawabnya, hendaknya Koperasi Tirta Lestari Banjarbaru dapat melakukan assesment dan masa percobaan terhadap penerimaan karyawan baru.

\section{DAFTAR PUSTAKA}

Hartadi, Bambang, 2018, Sistem Pengendalian Intern Dalam Hubungannya Dengan Manajemen dan Audit, Penerbit BPFE YKPN, Yogyakarta

Hongren, dkk, 2018, Akuntansi Di Indonesia, Salemba Empat, Jakarta

Jusup, Al Haryono, 2018, DasarDasar Akuntansi, Bagian Penerbit STIE YKPN, Yogyakarta

Karmani Kalmar, 2016, Analisis Sistem Pengendalian Intern Persediaan Barang Pada KSP Al Ikhlas Jember, http://sia.unjem.co.id (05/03/2020) Mulyadi. 2016. Sistem Akuntansi. Edisi
Ketiga, Cetakan Keempat. Salemba Empat : Jakarta

Mutmainah, 2016, Analisis Sistem Pengendalian Intern Persediaan Barang Dagangan Pada KSP Putra Mandiri Jember, http://sia.unjem.co.id (05/03/2020)

Prasetyo, Hari. 2016. Pengembangan Model Persediaan Dengan Mempertimbangkan Waktu Kadaluarsa dan Faktor Unit Diskon. Jurnal Ilmiah Teknik Industri. Volume 4 No. 3. Universitas Muhammadiyah : Surakarta

Rangkuti, Freddy, 2018, Manajemen Persediaan Aplikasi Di Bidang Bisnis, PT. Raja Grafindo Persada, Jakarta

Rosiana Eka Budiarti, 2015, Analisis Sistem Pengendalian Intern Persediaan Barang Dagangan Pada Koperasi Serba Usaha Ida Jember, http://sia.unjem.co.id (05/03/2020)

Sari. 2018. Sistem Akuntansi (Pendekatan Manajemen). Yogyakarta: Liberty.

Soemarso, SR, 2018, Akuntansi Suatu Pengantar, Salemba Empat, Jakarta

Zagladi, Arief Noviarakhman, Fredy Jayen, Sutrisno dan Melania, 2018, Pedoman Penulisan Skripsi STIE Pancasetia Banjarmasin, Pancasetia, Banjarmasin 